\title{
Supraglacial debris-transport variability over time: examples from Switzerland and Iceland
}

\author{
W. B. Whalley, C. F. Palmer, S.J. Hamilton and D. Kitchen \\ School of Geosciences, The Queen's University of Belfast, Belfast BT7 1.N.N, Northern Ireland
}

\begin{abstract}
The volume of debris in the left-lateral, Little Ice Age LIA: AD 1550-1850 moraine of the Feegletscher, Valais, Switzerland was compared with the actual volume being transported currently by the glacier. The latter is smaller by a factor of about two. In Tröllaskagi, north Iceland, a surface cover of debris on top of a very slow moving glacier ice mass (glacier noir, rock glacier) has been dated by lichenometry. The age of the oldest part is commensurate with LIA moraines in the area. Knowing the volume of debris of a given age allows an estimate of the debris supply to the glacier in a given time. Again, there appears to have been a significant reduction in debris to the glacier since the turn of the 19 th century. Debris input in the early LIA seems to have been particularly copious and this may be important in the formation of some glacier depositional forms such as rock glaciers.
\end{abstract}

\section{INTRODUGTION}

The basic controls of supraglacial debris supply to glaciers are well known. Debris from cliffs falls on to the accumulation area of a glacier, becomes englacial and subsequently emerges in the ablation area. The simplest resultant morphology is a moraine, terminal/lateral, sequence. However, there are surprisingly few quantitative data on debris input rates to glaciers. The study by Reheis (1975) on the Arapaho corrie glacier, Colorado Front Range, U.S.A., is the main example. It was possible in this case to calculate a denudation rate of the corrie backwall that supplied the debris to the glacier.

Retreat rates for cliffs which give rise to protalus ramparts/rock glaciers/protalus lobes have been determined for the Loch Lomond Stadial (Younger Dryas) in the British Isles by Ballantyne and Kirkbride (1987) and Wilson (1990). A problem in such cases is uncertainty as to the length of the major debris-supply period. Estimates from the Alps have been provided by Barsch (1977), using rock glaciers as records of debris supply. The more plentiful determinations of cliff retreat and debris supply from mountain area cliffs around the world (e.g. Gray, 1972; Gardner, 1983; André, 1986; Luckman and Fiske, 1995 are largely confined, however, to the present day.

Rate uniformity of geomorphological processes, including cliff weathering/denudation is often assumed, though with no valid reason. There is evidence that singular, high-magnitude events (usually rock falls) have contributed debris to glacier transport systems (see, e.g., Whalley (1974b) for review; Gordon and others, 1978), but there are no data which show that debris-input rates to glaciers might have changed over time. Obtaining data to show changing rates of rock debris-formation transport and deposition is difficult. Evidence that rock-cliff weathering rates have changed over time has been suggested, notably by Jäckli (1957) and Rapp (1960). Grove (1972) showed that tax records in Norway revealed a high incidence of natural catastrophes (including rock falls, etc.) during the Little Ice Age (LIA). A review of such data is given by Whalley (1984). The LIA is a period which may have produced rather different rates of debris supply to those of today, but this has not been easy to test, and nothing has yet shown that glacial systems have had differential debrissupply or transport rates. In this paper, we examine two glacial debris-transport systems to determine possible changes of debris supply rates from the LIA period to the present day. Different methods have been used to help control the uncertainties of field measurements.

In Switzerland, the left-lateral moraine of the north tongue of Feegletscher was examined (Whalley, 1978) together with other examples of large lateral moraines in the Alps. In Iceland the rock glacier in Nautárdalur was examined (Martin and Whalley, 1987).

\section{FEEGLETSCHER NORTH TONGUE}

\section{Moraine volume}

The moraine volume was calculated from digitized contours of an enlarged 1:10000 map. Various refinements were made to exclude material that might have been pre-LIA alluvium or moraine and the effect of spreading of debris in the terminal region. Local examination showed that the moraine bulk was not enhanced by a rock step or similar outcrop. Only the lateral moraine section has been used (Fig. 1), as some of the terminal moraine was deposited from material carried on the right side of the snout. Resistivity soundings 


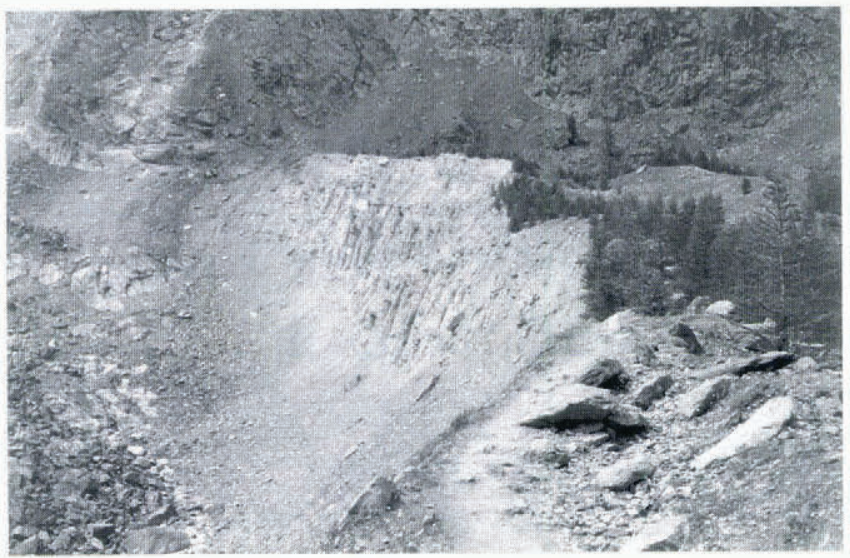

Fig. 1. Left-lateral moraine at Feegletscher north tongue, Valais, Switzerland.

suggest that no ice core of sufficient size to upset the calculation occurs in the moraine. An estimate of the voids ratio was made in order to reduce the moraine volume to an equivalent thickness of solid rock, so that useful comparisons could be made. This comparator is the solid-rock equivalent volume (SRE). After allowing for the measured voids ratio, a value for the lateral moraine volume was $3.7 \times 10^{6} \mathrm{~m}^{3}$.

\section{Present-day surface debris load}

The present-day supraglacial load was estimated and compared to past rates as calculated from the volume of moraine produced in the LIA. The debris can be regarded as a "crust" being carried down on the glacier surface.

Transverse lines to the centre of the glacier were set up on a section of glacier used for velocity determinations
(Fig. 2). Although the debris on the right of the centre line would not be expected to contribute to moraine construction on the left bank, some "safety" was built in by extending the area examined by about $20 \mathrm{~m}$ beyond the centre flowline.

In the first method, the transverse lines were followed with a compass, and the depth of debris was sampled at $2 \mathrm{~m}$ intervals with a ruler. As far as possible, readings were taken normal to the ice surface and to the upper level of the smaller particles $(<10 \mathrm{~cm})$. For larger particles a visual estimate of two-thirds of the height was made and the distance from the ice to that point was recorded. The results are shown in Figure 3. The voids ratio $(e)$ was found by collecting more detailed thickness measurements at randomly chosen points over a $20 \mathrm{~cm}$ square. This material was left on a polythene sheet to dry, then weighed, and from a density approximation (2.65), $e$ was calculated. It was found not to vary much between limits of 0.45 and 0.55 . From these estimates of thickness

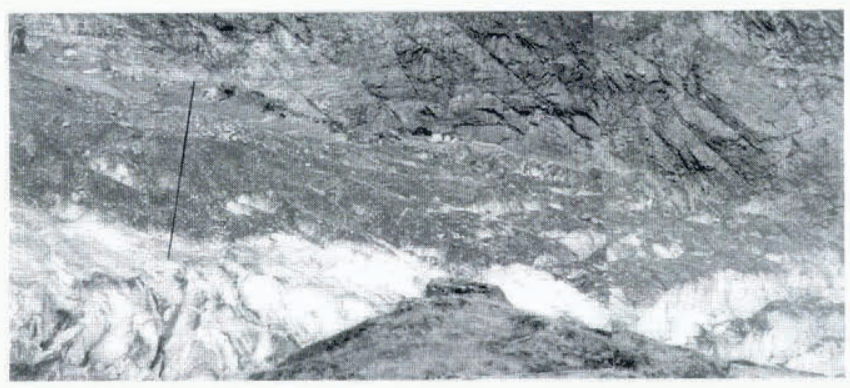

Fig. 2. Debris cover on the true left side of Feegletscher north tongue, flowing left to right, with part of the velocity line shown which was used to delimit the sampling area. The far side is north, the near side is south.

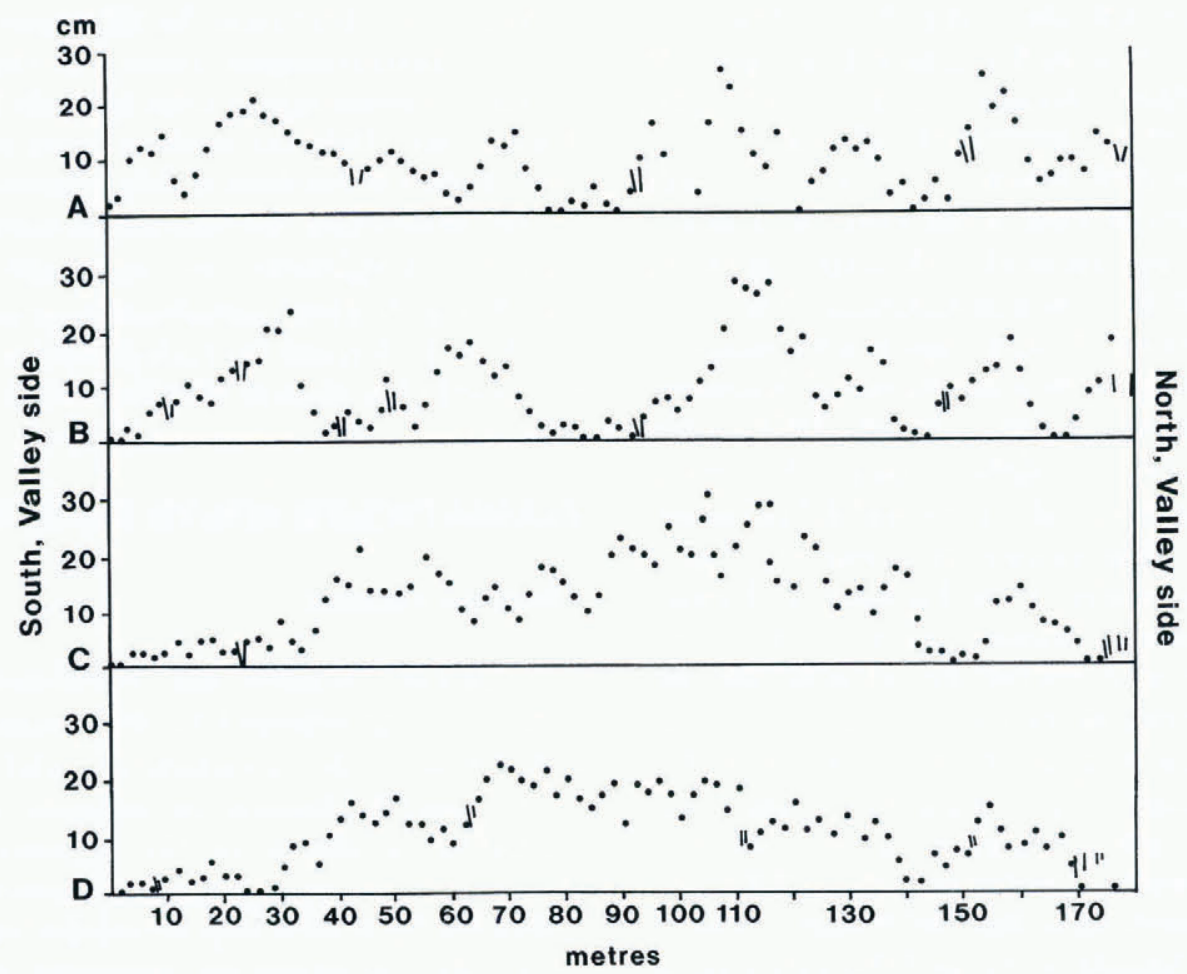

Fig. 3. Traverse lines across a glacier section from the centre line to the edge. The thickness of debris over the ice is as measured and has to be converted to solid-rock equivalent. The south side roughly delimils the glacier centre line (Fig. 1). 
and voids ratio the mean values of SRE for the transverse lines could be taken. Values of SRE are given for various conditions in Table 1.

A second, random sampling, method was used to calculate the SRE by weighing material in a square metre of surface debris within $100 \mathrm{~m}$ each side of the main velocity line. This value was then averaged and multiplied for the area of the section. The rather lower values of SRE obtained probably reflect the relatively low sampling density in some areas of the section. This method required more time and effort than the transverse depth sampling. The reason for taking a $200 \mathrm{~m}$ long section was to approximate the ice-discharge length across the section as a mean over the period of moraine construction. The value of present-day debris transport for a 350 year period was $1.57 \times 10^{6} \mathrm{~m}^{3}$. This value is certainly within the range provided by the first method.

\section{Glacier surface velocity}

Although present-day ice velocities have been determined for the ice tongue, there is a difficulty in estimating the variation in velocity through the LIA. There has been an ice-thinning of approximately $60 \mathrm{~m}$, estimated from trim lines, since the peak of the LIA. This was probably associated with a considerable reduction in velocity, although the surface gradient has probably increased only very slightly. A further problem is the variation of sliding velocity through time. Haefeli (1970) examined changes in the velocity of the Unteraargletscher over the previous 125 years and found that the annual velocity had been reduced by a factor of two. Sliding velocity reduction was mainly responsible for overall reduction. This makes it all the more difficult to estimate the velocity behaviour of Feegletscher. A further complication is the compressing flow regime at the present snout: debris would tend to be concentrated on a given surface area.

Using the above data, an estimate of the total potential debris discharge in the LIA can be made. It is evident that debris deposition on the main moraine had ended by AD 1900. Several periods of little or no construction occurred before then, although the glacier surface must have been accumulating debris before the main advance actually started. A time period for estimating the main construction $(t)$ of 350 years, from AD 1550 to 1900 , would seem to be reasonable and to err on the large side for safety. It is unlikely that the LIA advance started any earlier than AD
1600. Values of the required components are given in Table 1.

For a time period of 350 years (probably an overestimate), the volume of surface-transported debris is well below the volume of the moraine as previously calculated. Table 1 also shows the influence of different values of the parameters which affect potential moraine volume; some surface-transported volumes calculated were allowed to be on the high side for comparison. However, present-day transport rates (over 350 years) were still well below the estimated moraine volume of $3.7 \times 10^{6} \mathrm{~m}^{3}$ (SRE). An estimate of englacial load is given below.

Now there is a means of seeing, qualitatively, which of these estimates is the most realistic. The 350 years of moraine construction $(t)$ may be an overestimate, but the value of $V_{\mathrm{t}}$ (or $\left.Q_{\mathrm{d}} \times t\right)$ presumes that the supply of debris is continuous and at the same rate. A higher supply rate to the glacier would increase the overall value of $V_{\mathrm{t}}$, even at a constant glacier velocity, by increasing $d$ (or $1-e$ ). Similarly, if the debris supply rate to the glacier surface has always been the same as now, a faster moving glacier would apparently increase the value of $V_{\mathrm{t}}$. In fact it should remain the same because the value of $d$ (surface thickness of debris) is reduced. It is the input rate to the glacier which is significant, i.e., the glacier works like a conveyor belt. This makes it easier to estimate several variables. Thus, the 350 years seems to be quite adequate according to estimates of the moraine chronology (Whalley, 1974a). The velocity $(v)$ today is about $150 \mathrm{~m} \mathrm{a}^{-1}$ at a maximum; the width $(w)$ was probably little different in the past, but this is affected in similar manner to the glacier velocity. The main errors therefore would seem to come from mismeasurement of the surface debris quantity and voids ratio. It is difficult to know how much of a "safety" factor to add to this. The mean value of $d$ may, in any case, be a slight overestimation, but even so (Table 1) this analysis shows a large discrepancy in the moraine volume carried on the glacier today compared with the L.IA.

\section{Moraine-building: discussion}

It is doubtful whether the discrepancy between moraine volume and supraglacial transport could be reconciled without recourse to some explanation involving different rates of process of debris supply from those obtained now. It is assumed that the flow paths of debris have remained much the same over the LIA period. This is thought to be a reasonable assumption as the moraine is straight, being

Table 1. Values of solid-rock equivalent (SRE) volumes transported by Feegletscher, derived from estimates of surface debris thickness

\begin{tabular}{|c|c|c|c|c|c|c|}
\hline $\begin{array}{l}\text { Time period } t \\
\text { years }\end{array}$ & $\begin{array}{c}\text { Average depth } d \\
\mathrm{~m}\end{array}$ & $\begin{array}{l}\text { Glacier velocity v } \\
\qquad \mathrm{m} \mathrm{a}^{-1}\end{array}$ & Voids ratio e & $1-e$ & $\begin{array}{c}\text { Width } \\
\mathrm{m}\end{array}$ & $\begin{array}{c}\text { Debris flux } V_{\mathrm{t}} \\
\quad \times 10^{6} \mathrm{~m}^{3}\end{array}$ \\
\hline 350 & 0.15 & 200 & 0.45 & 0.55 & 180 & 1.0 \\
\hline 350 & 0.2 & 200 & 0.45 & 0.55 & 180 & 1.4 \\
\hline 400 & 0.2 & 200 & 0.45 & 0.55 & 180 & 1.6 \\
\hline 350 & 0.2 & 200 & 0.4 & 0.6 & 180 & 1.5 \\
\hline 350 & 0.25 & 200 & 0.45 & 0.55 & 180 & 1.7 \\
\hline
\end{tabular}


a direct continuation of the line of the valley upstream. There are, however, other process differences which must be taken into account. If, at the outset, it is presumed that a subglacial source can be excluded from the analysis, then there are three hypotheses to consider:

1. That the englacial debris supply was once greater than at present.

2. That the material lost from the surface of the glacier down crevasses or by being washed away before it could be deposited is now greater than it was during the main moraine-building period. This material would not be measured in the estimation given above.

3. That the rate of debris supply to the glacier has slowed down over the last 50 years or so. Roughly, 50 years is the time taken for supraglacial material to reach the sample traverse line.

\section{The importance of englacial material}

It is possible that there was much more englacial debris carried by the glacier in the LIA than now. Only ice at the base of the glacier which has had a long flow path might be representative of it, so the debris content here was sampled in a tunnel at the snout (Whalley, 1974a). Most englacial material would have become supraglacial by the time the lowest (moraine-building) section of the glacier was reached; hence, a measure of the supraglacial load at the moment can still be compared with LIA conditions. A correction can then be applied to allow for the englacial content emerging below the traverse sampling lines. Using debris contents from the tunnel, a maximum of $0.8 \times 10^{6} \mathrm{~m}^{3} \mathrm{SRE}$ over 350 years could have been supplied, although this addition cannot bridge the discrepancy in glacier-surface/moraine volumes.

\section{Material lost from the glacier surface}

There may have been less debris loss from a supra- to an englacial position in the LIA than is found today. Loss of fines by stream-washing was not observed; similarly, close study has shown that very little debris falls down crevasses unless the debris thickness is more than about $300 \mathrm{~mm}$, which is rare on Feegletscher. Examination of crevasses does show some debris within them, but as the sampling of surface debris was taken on a relatively flat area most englacial crevasse debris had melted out back on to the surface before the sampling zone was reached. Hence, with the sampling site used, a good estimate of the potential moraine-forming load could be formed and corrections for possible misestimates of past differences in the debris load kept to a minimum. There appears to be no evidence for a higher loss of material from the surface of the glacier at the present time compared with the period of moraine construction.

\section{Higher rates of debris transport in the past}

This must now be considered a distinct possibility at Feegletscher. Any increased precipitation during the LIA would tend to have the effect of increasing the number and size of avalanches and other means of removing debris from the mountain walls which supply the glacier. If the rate of debris supply before the LIA was lower than at present, then it is possible that more rapid removal of material from cliffs on to the glacier during its period of growth could have had a marked effect on the debris supply to the moraines. Unfortunately, it is very difficult to test this more detailed aspect of the hypothesis.

A further possibility is that there was a greater supply of debris from cliffs by direct weathering, giving events that were larger than have often taken place over the last 100 years or so. A cliff fall on to the snout of Feegletscher in 1954 and the identification of other such events in the neighbourhood suggest that this might be a case which is frequently overlooked. There is some evidence to suggest that there was more debris supplied by these lowfrequency events in the past. The subject is reviewed and discussed by Whalley (1974b).

\section{NAUTÁRDALUR, NORTH ICELAND: DEBRIS- VOLUME DETERMINATIONS}

This rock glacier has been described previously by Martin and Whalley (1987). The investigations reported by Whalley and others (1994) show that the debris lies on top of a glacier ice core. Although it has not been possible to determine the depth of the debris cover everywhere, the

Table 2. Approximately dated zones 1-6 (see Fig. 4) with corresponding areas and debris thicknesses (estimated for two values) on Nautaidalur rock glacier. This suggests that the maximum debris transport occurred early in the Little Ice Age

\begin{tabular}{|c|c|c|c|c|c|c|c|c|}
\hline \multirow[t]{2}{*}{ Zone } & Area & $\begin{array}{c}\text { Average debris } \\
\text { thickness } \\
\text { estimate } 1\end{array}$ & Vol. 1 & $\%$ & $\begin{array}{c}\text { Average debris } \\
\text { thickness } \\
\text { estimate } 2\end{array}$ & Vol. 2 & $\%$ & Age span \\
\hline & $\mathrm{m}^{2}$ & $\mathrm{~m}$ & $\mathrm{~m}^{3}$ & & $\mathrm{~m}$ & $\mathrm{~m}^{3}$ & & years \\
\hline 1 & 10625 & 1 & 10625 & 13 & 1.5 & 15938 & 12 & $>200$ \\
\hline 2 & 26250 & 1 & 26250 & 31 & 1.5 & 39375 & 29 & 200 \\
\hline 3 & 26875 & 1 & 26875 & 32 & 1.5 & 40312 & 30 & $200-150$ \\
\hline 4 & 25000 & 0.5 & 12500 & 15 & 1 & 25000 & 18 & $150-100$ \\
\hline 5 & 23750 & 0.25 & 5938 & 7 & 0.5 & 11875 & 9 & $100-50$ \\
\hline 6 & 16250 & 0.1 & 1625 & 2 & 0.25 & 4062 & 3 & $<50$ \\
\hline
\end{tabular}


general pattern has been determined from both pits and accidental discoveries of debris overlying ice (e.g. Whalley and Martin, 1992; Martin and others, 1994). Table 2 shows the relevant depths (with ranges of values to show the volumetric calculations). Detailed lichenometric investigations (Hamilton and Whalley, 1995) have shown that the age of the surface of the rock glacier can be accounted for within a 200 year time period. Furthermore, approximate ages of the glacier surface can be determined (Fig. 4). This is roughly coincident with the banding of debris seen on the glacier surface (e.g. Martin and Whalley, 1987). Thus, it is possible to produce a rate-ofsupply calculation for various times of deposition. This can be compared with the present-day debris supply rate which is also an end member of the age sequence. The values are seen in Table 2.

The main problem in assessing the debris volume is on the outer rim of the rock glacier and at the snout. The latter has a relatively thin cover in some areas (Martin and Whalley, 1987) but is thicker in others and at the sides. However, combining zones 1 and 2, there is clearly a large volume input at the start of rock glacier formation.

Present-day input rates are small, as seen not only from the volume of zone 6 on Nautárdalur but also from measurement of the present-day input. Debris from the cliffs now falls (rolls or is avalanched) down a relatively

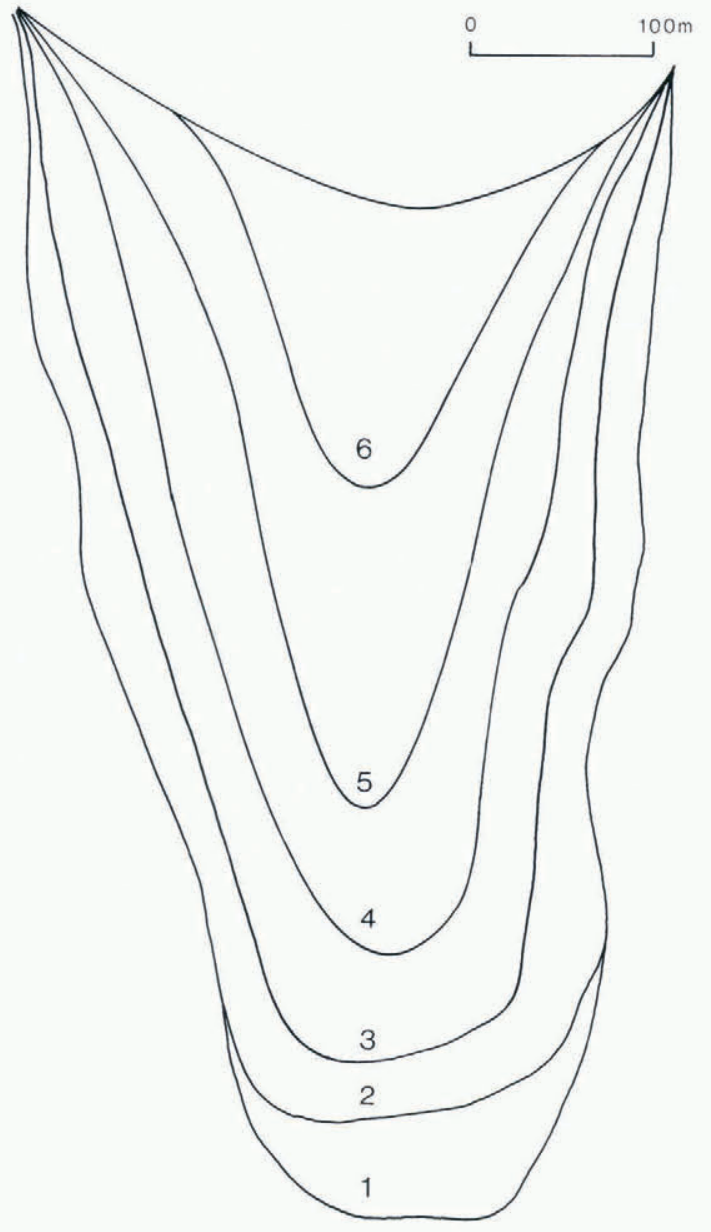

Fig. 4. Nautárdalur rock glacier with zones derived according to approximate ages. The zones are numbered from oldest, 1 (about 200 years) to present day, 6. The volumes derived are seen in Table 2. short distance from the corrie backwall. Very rarely today does any debris reach the rock glacier. The latter debris supply comes predominantly from material emerging from the debris bands in the lower ablation zone of the exposed corrie glacier. LIA debris input seems to have been from small-scale but relatively "continuous" rock fall from the backwall and not from a very few highmagnitude events.

The lack of recent debris input into the rock glacier system can also be seen from the way substantial ice ablation currently occurs at the junction between the corrie glacier and the rock glacier. Ice-melting is greatest here, being some $22 \mathrm{~m}$ in the centre of the rock glacier below the outer ridges of the rock glacier (Whalley and others, 1995). If present debris-supply rates were as great as in the past, then it is unlikely that the ablation would be as rapid, as there would be a thick debris blanket.

\section{IMPLICATIONS FOR ROCK GLACIER FORMATION}

The glacier ice-core model of rock glacier formation is generally considered to be one of simple surface debris accumulation on a decaying glacier. In this view, the glacier does not have the capability of removing the debris as it decays. Thus a "glacier blanc" turns into a "glacier noir". However, as the surface-accumulating debris will tend to prevent further ice-melting, the debris supply from englacial to supraglacial is largely selflimiting. The simplest way in which debris can be accumulated on the glacier body with sufficient thickness to prevent substantial melting is to load the glacier at an early stage in its development, i.e. when it is increasing in extent and volume. This situation could be achieved easily by a high debris production load at the beginning of the LIA. Both estimates derived in this paper show this to be a likely case. Another factor necessary to note is that there is no moraine in front of the glacier (or any of the rock glaciers in Tröllaskagi) relating to the LIA. This again suggests that the formative period was at the start rather than the end of rock glacier formation.

\section{DEBRIS SUPPLY TO GLACIERS AND TRANSPORT - GENERAL DISCUSSION}

Despite very great difficulties in obtaining an accurate assessment of debris transport throughout the LIA it appears that by adding various methodological safeguards a reasonable conclusion can be achieved. Englacially transported debris was apparently not important in moraine construction, because of its limited volume. Today, as when the moraine was being built, englacial material can be treated ultimately as a supraglacial load. The past input to the glacier surface seems to have been rather greater than the present input. This is apparently valid for the LIA and it seems probable that the early LIA had the greatest transport of material because the cliffs which supply the debris were being "swept" by increasing frequency or severity of water or avalanches and/or perhaps because of an 
increase in rock-fall activity. It is not known whether frost action per se played an important role here, although there is some evidence to suggest this (Whalley, 1974b). This basically climatic consequence of the LIA appears to fit the small amount of evidence from elsewhere suggesting greater geomorphic activity than today.

The influence of debris-supply rates on glacier dynamics is important, especially where the ice supply has also changed markedly over time. The reason why Feegletscher (or indeed most "large" glaciers) do not form rock glaciers is because there is sufficient ice to remove most of the debris and form moraines. Latterly (post-LIA) where the ice discharge has declined, then glaciers may accrete a heavy debris load (glaciers noirs). This does not mean that all rock glaciers are formed in this way, or even that a rock glacier is merely a debriscovered glacier. An implication of this work is that rock glaciers have a different sequence of formation than most debris-covered glaciers as usually conceived, and a different set of dynamic conditions.

\section{CONCLUSIONS}

We suggest that LIA debris-transport rates, or rates supplied to a glacier system, may have been substantially greater than determined from present-day observations. It is thought that the debris supply was more pronounced in the early LIA when glaciers grew in size, and geomorphological activity increased. In some cases this might have been due to catastrophic rock falls (berghlaup, Bergsturz), but it seems best attributed to increased activity of small rock falls of low magnitude but high frequency.

It is important to recognise the influence of high debris-input rates on to glacial systems, as this may modify the glacier dynamics. This is the case not only for small glaciers which might become rock glaciers but also with respect to the dynamics of large glaciers modified by high-magnitude, low-frequency events.

\section{ACKNOWLEDGEMENTS}

We thank the many field-workers and expedition supporters over the years who have helped in these projects; in particular, the Earthwatch 1993 members. C.F.P. and S.J.H. are in receipt of Department of Education for Northern Ireland postgraduate studentships, and D.K. is in receipt of a European Science Foundation award.

\section{REFERENCES}

André, M. -F. 1986. Dating slope deposits and estimating rates of rock wall retreat in northwest Spitsbergen by lichenometry. Geogr. Ann. 68A $(1-2), 65-75$.

Ballantyne, C.K. and M.P. Kirkbride. 1987. Rockfall activity in upland Britain during the Loch Lomond stadial. Geogr. J., 153(1), 8692.

Gardner, J.S. 1983. Rockfall frequency and distribution in the Highwood Pass area, Canadian Rocky Mountains. Z. Geomorphol. $27(3), 311-324$.

Gordon, J. E., R. V. Birnic and R.J. Timmis. 1978. A major rockfall and debris slide on the Lyell Glacier, South Georgia. Arct. Alp. Res., $10(1)$ $49-60$.

Gray, J. T. 1972. Debris accretion on talus slopes in the central Yukon Territory, BC Geogr. Ser. 14, $75-84$.

Grove, J. M. 1972. The incidences of landslides, avalanches and floods in western Norway during the Little Ice Age. Arct. Alp. Res., 4(2), 131138.

Hacfeli, R. 1970. Changes in the behaviour of the Unteraargletscher in the last 125 years. F. Glaciol., 9(56), 195212.

Hamilton, S.J. and W. B. Whalley. 1995. Preliminary results from the lichenometric study of the Nautardalur rock glacier, Tröllaskagi, northern Iceland. Geomorphology, 12 2), 123-132.

Jäckli, H. 1957. Gegenwartsgeologie des bündnerischen Rheingebietes: ein Beitrag zur exogenen Dynamik Alpiner Gebirgslandschaften. Beitr. Geol. Karte Schweiz. Geotech. Ser. 36.

Luckman, B.H. and C.J. Fiske. 1995. Estimating long-term rockfall accretion rates by lichenometry. In Slaymaker, O., ed. Steepland geomorphology. Chichester, etc., John Wiley and Sons, 233- 255.

Martin, H. E. and W. B. Whalley. 1987. A glacier ice-cored rock glacier, Tröllaskagi, Iceland. Jökull, 37, 49-55.

Martin, H.E., W.B. Whalley, J. Orr and C.J. Caseldine. 1994. Lichenometric measurements on rock glaciers from Tröllaskagi, north Iceland. Münch. Geogr. Abh., Ser. B, 12, 205-224.

Rapp, A. 1960. Recent development of mountain slopes in Kärkevagge and surroundings, northern Scandinavia. Geogr. Ann., 42 2-3), 65 200.

Reheis, M.J. 1975. Source, transportation and deposition of debris on Arapaho Glacier, Front Range, Colorado, U.S.A. J. Glaciol., 14(72), 407-420.

Whalley, W. B. 1974a. The formation and characteristics of some Alpine moraines. (Ph.D. thesis, University of Cambridge.

Whalley, W. B. 1974b. The mechanics of high-magnilude, low-frequency rock failure, Reading, etc., Reading University. Department of Geography. (Geographical Papers 27.)

Whalley, W.B. 1978. Abnormally steep slopes on moraines constructed by valley glaciers. In The engineering behaviour of glacial materials. Proceedings of the Symposium held at the University of Birmingham ... 1975. Norwich, Geo Abstracts, $60-66$.

Whalley, W. B. 1984. Rockfalls. In Brunsden, D. and D. B. Prior, eds. Slope instability. Chichester, etc., John Wiley and Sons, 217-256.

Whalley, W. B. and H. E. Martin. 1992. Rock glaciers: II. Models and mechanisms. Prog. Phys. Geogr., 16 (2), 127-186.

Whalley, W. B., C. Palmer, S. Hamilton and J. Gordon. 1994. Correspondence. Ice exposures in rock glaciers. 7. Glaciol., 40 135), $427-429$.

Whalley, W. B., S.J. Hamilton, C. F. Palmer, J. E. Gordon and H. E. Martin. 1995. The dynamics of rock glaciers: data from Tröllaskagi, north Iceland. In Slaymaker, O., ed. Steepland geomorphology. Chichester, etc., John Wiley and Sons, 129-145.

Wilson, P. 1990. Characteristics and significance of protalus ramparts and fossil rock glaciers on Errigal Mountain, Co. Donegal. Proc. R. Ir. Acad., Ser. B, 90, 1-21 